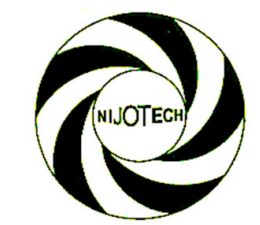

Nigerian Journal of Technology (NIJOTECH)

Vol. 35, No. 1, January 2016, pp. 31 - 36

Copyright@ Faculty of Engineering, University of Nigeria, Nsukka,

Print ISSN: 0331-8443, Electronic ISSN: 2467-8821

www.nijotech.com

http://dx.doi.org/10.4314/njt.v35i1.5

\title{
THE POTENTIAL USE OF FONIO HUSK ASH AS A POZZOLANA IN CONCRETE
}

\author{
E. E. Ndububa ${ }^{1, *}$, J. S. Okonkwo ${ }^{2}$ and O. I. Ndububa ${ }^{3}$ \\ 1 Department of Civil Engineering, University of Abuja, GWagwalada, Abuja. NIGERIA \\ 2 Department of Civil Engineering, The Federal Polytechnic, Bauchi, Bauchi State. NIGERIA \\ 3 DePartment of Civil EngineERING, FEDERAl University, OYe EKITI, EKITI STATE. NIGERIA \\ E-mail addresses:1 ndububaee@yahoo.com, ${ }^{2}$ amakamodupe@yahoo.com,3ndububaoi@yahoo.com
}

\begin{abstract}
Fonio husk, an agro-waste was incinerated up to a temperature of $600{ }^{\circ} \mathrm{C}$ and converted into ash. The Fonio Husk Ash (FHA) was used as a partial replacement for Ordinary Portland Cement (OPC) in concrete. The use was expected to reduce environmental pollution and cost on cement. The replacement levels of 0\%, 5\%, 10\%, 15\%, 20\% and 25\% ash were used. The chemical constituents of the FHA as determined from an X-Ray diffraction analyzer included $\mathrm{SiO}_{2}$ (59.45\%), $\mathrm{Al}_{2} \mathrm{O}_{3}$ (8.19\%), $\mathrm{K}_{2} \mathrm{O}$ (5.20), $\mathrm{Fe}_{2} \mathrm{O}_{3}$ (3.51\%), $\mathrm{CaO}$ (2.70\%) and $\mathrm{MgO}$ (1.92\%). The combined percent of $\mathrm{SiO}_{2}, \mathrm{Al}_{2} \mathrm{O}_{3}$ and $\mathrm{Fe}_{2} \mathrm{O}_{3}$ of $71.14 \%$ is above the $70 \%$ benchmark for a pozzolana material. The Initial and Final Setting Times of the FHA-Cement paste increased with the increase of FHA up to an optimum of 15\% replacement before decreasing. The values were 190 minutes and 205minutes respectively at 5\% replacements, and higher than those for plain cement which were 145 and 195 minutes respectively. For 1:2:4 mixes, the FHA Concrete (FHAC) gave compressive strength values in the range of $26.89 \mathrm{~N} / \mathrm{mm}^{2}$ for $5 \%$ ash and $10.00 \mathrm{~N} / \mathrm{mm}^{2}$ for $25 \%$ ash at 28 days curing period. The plain concrete had a value of $24.98 \mathrm{~N} / \mathrm{mm}^{2}$. The trend showed that 10\% FHA should not be exceeded for an optimum strength value. The flexural strength values decreased with increase in FHA replacement. The density also followed the trend though marginally. The FHAC will be suitable for mass concreting and use in hot weather.
\end{abstract}

Keywords: Fonio, Husk Ash, Compressive Strength, Cement, Concrete, Pozzolana.

\section{INTRODUCTION}

Cement is an important constituent in the concrete composite. However its cost is relatively very high. This has impacted in the cost of concrete production and by extension on the cost of housing delivery in Nigeria. An option available in mitigating this challenge is in replacing a proportion of cement with cheap and available pozzolanic materials from agro wastes.

Results of a report [1] on the comparative cost analysis of pozzolana in concrete from agro-wastes showed that rice husk ash best satisfied the cost requirement at a price equivalent of cement of 1015 using the $50 \mathrm{~kg}$ bag size. The market price of cement at the time of the research hereby reported hovered around N2,000 for the same bag size.

ASTM C618 [2] defined pozzolana as "siliceous or siliceous and aluminous material which in themselves have little or no cementitous properties but in finely divided form and in the presence of moisture they can react with calcium hydroxide which is liberated during the hydration of Portland cement at ordinary temperatures to form compounds possessing cementitous properties". Pozzolana have the characteristics of combining with the free lime liberated during the hydration process of OPC to produce stable, insoluble calcium silicates thus reducing the process of mortar and concrete attacks from sulphates, salts and chlorides [3].

The free limes are shown in the hydration equations of cement as given below [4]:

$$
\begin{aligned}
& \mathrm{C}_{3} \mathrm{~S}+6 \mathrm{H}=\mathrm{C}_{3} \mathrm{~S}_{2} \mathrm{H}_{3}+3 \mathrm{Ca}(\mathrm{OH})_{2} \\
& 2 \mathrm{C}_{2} \mathrm{~S}+4 \mathrm{H}=\mathrm{C}_{3} \mathrm{~S}_{2} \mathrm{H}_{3}+\mathrm{Ca}(\mathrm{OH})_{2}
\end{aligned}
$$

Where $\mathrm{C}_{3} \mathrm{~S}$ and $\mathrm{C}_{2} \mathrm{~S}$ are the Tricalcium Silicate and Dicalcium Silicate compounds in cement. $\mathrm{Ca}(\mathrm{OH})_{2}$ is the free lime (Calcium Hydroxide). 
By-products mineral admixtures such as fly ash, rice husk ash and ground granulated blast furnace slag contribute to improvement of concrete performance (for example, high strength, high durability and reduction of heat of hydration) as well as reduction of energy and carbon dioxide generated in the production of cement [5].

Fonio is the name given to cultivated grains in the Digitaria genius. It is called "Acha" by Hausa speaking people of Northern Nigeria. The grains are quite small and look like millet in appearance. It is commonly found in West Africa and presents itself in two forms namely; White Fonio (Digitaria Exilis) and Black Fonio (Digitarialburua). Among these two varieties, the white fonio is the most important and popular due to its uses and ease of cultivation. De-husking of the fonio seed is done traditionally by pounding the harvested fruit in a mortar with sand and then separating the grains, sand and husk by winnowing and further pounding. Fonio husks are the hard protecting coverings of the grains.

Fonio has the potential just like any other common cereal to improve nutrition. It is used to prepare porridge and in bakery. It is also used in brewery and drug manufacturing. After harvest, the husk is often heaped up to constitute environmental nuisance. This is often the case with post-harvest Agricultural wastes. The problem of waste accumulation exists worldwide. The use of rejected materials is a subject of world research [6]. The Fonio husk is no exemption, being a post-harvest Agro-waste material. Sometimes they are fed to livestock and used for fuel generation by the locals.

Extensive research activities has been carried out on the ashes of many agro waste materials with the intent of producing concrete and mortar through partial replacement of OPC. In the case of Rice Husk Ash (RHA) - cement composites, it was shown that at $\mathrm{w} / \mathrm{c}$ ratio of 0.30 and OPC replacement level of $20 \%$, RHA mortar resulted in higher compressive strength compared to the control for both water cured and uncured cubes. It also improved in durability properties [7]. At the same $20 \%$ in another report [8], compressive strength and porosity of cement mortar showed better result over plain mortar. Still on RHA mortar, two reports gave optimum compressive strengths at $10 \%$ and $15 \%$ respectively [9], [10]. Also the presence of RHA and cement kiln dust in cement pastes improved the resistance of the mortar to sulfuric acid attack [11].

Palm Kernel Shell Ash (PKSA) did not improve the strength of concrete. It was reported that at $10 \%$ replacement level the compressive strength was 22.8 $\mathrm{N} / \mathrm{mm}^{2}$ after 28 days of curing [12]. In another report, Palm Oil Fuel Ash (POFA) improved the strength, chloride and corrosion resistance of concrete at $20 \%$ optimum replacement level [13]. Similar work was conducted on Bamboo Leaf Ash with encouraging results [14].

In the case of Guinea Corn Husk Ash (GCHA), it was conveniently concluded in a report that after 28 days curing period the optimum strength of $26.27 \mathrm{~N} / \mathrm{mm}^{2}$ was at $5 \%$ replacement level while plain concrete had a value of $25.50 \mathrm{~N} / \mathrm{mm}^{2}$ [15].

This paper examines the effect of FHA on concrete by reporting the results of the chemical composition of FHA from an X - Ray Diffraction (XRF) Analysis Test, the Setting Times of FHA-cement paste, Compressive and Flexural strengths of FHAC, and Density of the same. The results showed that the chemical composition of FHA gave it away as a Pozzolanic material and the values of Initial Setting Time (IST) and Final Setting Time (FST) increased as the percentage of ash increased.

The compressive strength improved at 5\% replacement level but depreciated hence after. The flexural strength values equally decreased, though at every replacement level. The FHAC promises to be a viable alternative to conventional concrete. Builders can therefore use FHA as a replacement for cement in concrete and mortar production. This will reduce cost of construction especially in parts of West Africa where Fonio is grown. Optimum values are however obtainable at values not exceeding $15 \%$.

\section{MATERIALS AND METHODS}

The materials used included OPC, Fine and Coarse Aggregates, FHA and water. The OPC was procured from Ashaka Cement Works in Gombe state of Nigeria. The Fine and Coarse aggregates were obtained from the Bauchi town environs in Nigeria. The Fonio husk from which FHA was obtained was locally sourced from farms around BarkinLadi, near Jos in Plateau State of Nigeria. FHA replacement levels of $5 \%, 10 \%$, $15 \%, 20 \%$ and $25 \%$ by weight were investigated with plain concrete/mortar (0\% FHA) as control.

\subsection{Preparations of Materials}

The OPC was procured as packaged in $50 \mathrm{Kg}$ bags before use. Fine and Coarse aggregates were sieved with the largest particles at $2.36 \mathrm{~mm}$ and $20 \mathrm{~mm}$ respectively in the BSI sieve. Samples of the Fonio 
husk were burnt up to $600^{\circ} \mathrm{C}$ using a regulated incinerator at the Industrial Design Programme of the Abubakar Tafawa Balewa University Bauchi. The ash was allowed to cool before grinding to a very fine texture and then allowed to pass through 0.250 ASTM sieve $(250 \mu \mathrm{m})$. Clean tap water from the laboratory was used, it had no impurities. The tap water source was from boreholes that supplied the campus.

\subsection{Chemical Analysis of FHA}

The ash was analyzed to determine the composition of its constituent chemicals and its suitability as a pozzolana. The chemical analysis was conducted at the Lafarge Cement Plant in Ashaka, Gombe State, Nigeria. The X-Ray Diffraction Analyzer (XRF test) was used for the analysis. This provided the percent composition of the oxide constituents of the ash. The Bogue composition equation was also used to compute the composition of Tricalcium Silicate $\left(\mathrm{C}_{3} \mathrm{~S}\right)$ and the Dicalcium Silicate $\left(\mathrm{C}_{2} \mathrm{~S}\right)$ in the ash. The composition equation is given as [4]:

$$
\begin{aligned}
C_{3} S= & 4.07 \mathrm{CaO}-7.60 \mathrm{Al}_{2} \mathrm{O}_{3}-1.43 \mathrm{Fe}_{2} \mathrm{O}_{3} \\
& -2.85 \mathrm{SO}_{3} \\
C_{2} \mathrm{~S}=2.87 \mathrm{SiO}_{2}- & 0.75 \mathrm{C}_{3}
\end{aligned}
$$

\subsection{Consistency and setting times of the FHA-Cement paste}

The vicat apparatus was used to determine the consistency and setting time of the pozzolanic paste in accordance with BS1881 [16].The water cement ratio that gives a plunger penetration of 5 to $7 \mathrm{~mm}$ above the bottom of the mould is the standard consistency. The Initial Setting Time (IST) is the time taken from mixing with water until the paste has stiffened for the needle to penetrate not deeper than $5 \mathrm{~mm}$ above the bottom of the mould. The Final Setting Time (FST) is determined by replacing the needle with annular attachment. The FST is the time from mixing with water to when the needle makes an impression on the surface but annular cutting edge fails to do so.The above experiments were repeated for $0 \%, 5 \%, 10 \%$, $15 \%, 20 \%$, and $25 \%$ replacement levels.

\subsection{Moisture Content (M.C)}

This was conducted according to BS 812, part 109 [17]. Three samples each of FHA, Fine sand, Coarse aggregate and OPC were taken each put into a clean tin container respectively with a known weight, then the sample and the weight of the container were determined. The samples were then left in the oven for 24 hours at a temperature of $100^{\circ} \mathrm{C}$. It was removed and weighed. The average of the values were used. The moisture content was calculated using:

$$
\text { M. C }=\frac{\text { Wet Weight }- \text { Dry Weight }}{\text { Dry Weight }} \times 100
$$

\subsection{Compressive Strength Test}

The compressive strength test was conducted in accordance with ASTM Standards [18]. FHAC cubes with size $150 \times 150150 \mathrm{~mm}$ were moulded. The 1: 2: 4 mix ratio was adopted. The ratio was that of OPC (with levels of FHA), fine aggregate and coarse aggregate. The water - cement ratio was 0.65 . The cubes were cast for replacement levels of $0 \%, 5 \%$, $10 \%, 15 \%, 20 \%$, and $25 \%$ and cured for 7 days and 28 days respectively. For each mix, 3 cubes were crushed to obtain the average strength.

The compressive strength is a measure of the ratio of the crushing force over the cross sectional area of the cube.

\subsection{Flexural Strength Test}

The flexural strength (or Modulus of Rupture) test of the beams was performed using a mould of $450 \mathrm{~mm} \mathrm{x}$ $150 \mathrm{~mm} \times 150 \mathrm{~mm}$ in accordance with ASTM [19]. 72 beams with 1:2:4 mixes were cast for replacement levels of $0 \%, 5 \%, 10 \%, 15 \%, 20 \%$, and $25 \%$ and cured for 7 days and 28 days respectively. For each mix, three beams were crushed to obtain the average Modulus of Rupture (MOR). The symmetrical twopoint loading approach was adopted and the MOR was computed from the expression:

$$
M O R=\frac{P L}{(b d) 2}
$$

Where, $\mathrm{P}$ is maximum total load on the beam, $\mathrm{L}$ is the span, $b$ is the width of the beam and $d$ is the depth of the beam.

\subsection{Density Test}

This was carried out in accordance with BS 1881, Part 114 [20] and in conjunction with compressive strength test. At the end of each curing period, the concrete cubes were weighed using an electric weighing machine balance. The averages of 3 samples were used. Density is calculated as mass of mortar cube $(\mathrm{kg})$ divided by volume of mortar cube $\left(\mathrm{m}^{3}\right)$ and expressed in $\mathrm{kg} / \mathrm{m}^{3}$. 
Table 1: Result of Chemical Analysis of FHA

\begin{tabular}{|c|c|c|c|c|c|c|c|c|c|c|c|c|}
\hline Constituent & $\mathrm{S}_{i} \mathrm{O}_{2}$ & $\mathrm{AL}_{2} \mathrm{O}_{3}$ & $\mathrm{Fe}_{2} \mathrm{O}_{3}$ & $\mathrm{CaO}$ & $\mathrm{MgO}$ & $\mathrm{T}_{\mathrm{i}} \mathrm{O}_{2}$ & $\mathrm{MnO}_{3}$ & $\mathrm{P}_{2} \mathrm{O}_{5}$ & $\mathrm{~K}_{2} \mathrm{O}$ & $\mathrm{SO}_{3}$ & $\mathrm{~L}_{2} \mathrm{O} . \mathrm{I}$ & $\mathrm{Na}_{2} \mathrm{O}$ \\
\hline \% by weight & 59.05 & 7.89 & 3.12 & 2.63 & 1.73 & 0.70 & 0.25 & 0.80 & 4.80 & 0.30 & 20.25 & 0.80 \\
\hline
\end{tabular}

\section{RESULTS AND DISCUSSION}

\subsection{Chemical Analysis}

The results of the chemical analysis are shown in Table 1. The total combined content of silica $\left(\mathrm{SiO}_{2}\right)$, alumina $\left(\mathrm{Al}_{2} \mathrm{O}_{3}\right)$ and ferric oxide $\left(\mathrm{Fe}_{2} \mathrm{O}_{3}\right)$ was $71.14 \%$. ASTM C618 [2] specifies that any pozzolana that will be used as a cement blender in concrete requires a combined minimum of $70 \%$ of silica, alumina and ferric oxide. Hence FHA is suitable as a pozzolana in concrete production. Also $\mathrm{SO}_{3}$ content of $0.30 \%$ is below the maximum content of $5 \%$ specified in the same ASTM C 618. An excess of $\mathrm{SO}_{3}$ can lead to expansion and subsequent disruption of the set cement paste. The ash was therefore adjudged a suitable pozzolana.

\subsection{Some Physical Properties of FHAC Constituents}

The Table 2 shows some physical values of the FHAC composite constituents used in the experimental programme. The physical properties include moisture content of FHA-cement paste, fineness modulus and pH of FHA. The results show that FHA had higher water content and as expected, an alkaline material.

Table 2: Test Results on FHAC Composite Constituents

\begin{tabular}{cccc}
\hline Material & $\begin{array}{c}\text { Moisture } \\
\text { content }\end{array}$ & $\begin{array}{c}\text { Fineness } \\
\text { Modulus (\%) }\end{array}$ & $\begin{array}{c}\mathrm{pH} \\
\text { value }\end{array}$ \\
\hline OPC & 0.54 & - & - \\
FHA & 2.17 & - & 7.90 \\
$\begin{array}{c}\text { Fine } \\
\text { Aggregate } \\
\text { Coarse } \\
\text { Aggregate }\end{array}$ & 1.05 & 3.29 & - \\
\hline
\end{tabular}

\subsection{Consistency and Setting Times of the Pozzolana Paste}

The result of the standard consistency and setting times of the pozzolana paste are shown in Table 3. It was observed that the consistency of the paste decreased with the increase in percentage replacement of FHA. This strongly suggest that FHA can serve as a water reducing admixture in concreting. Also the IST and FST increased with increase in FHA content. Calculated results from equations (3) and (4) gave $\mathrm{C}_{3} \mathrm{~S}$ and $\mathrm{C}_{2} \mathrm{~S}$ values of -496.41 and 541.78 respectively. The typical OPC values are54.1 and16.6 respectively. The insignificant value of $\mathrm{C}_{3} \mathrm{~S}$ in FHA only attest to the very low $\mathrm{CaO}$ content in FHA. This confirms that FHA and indeed pozzolanas generally do not possess much lime of their own but use the lime produced from equations shown in (1) and (2) to produce binding properties. The very high $\mathrm{C}_{2} \mathrm{~S}$ value show that FHA has very high $\mathrm{SiO}_{2}$ component. Since $\mathrm{C}_{2} \mathrm{~S}$ is controlled by its slow intrinsic slow rate of reaction, then its' very high composition in FHA may have contributed to the slower setting times when compared with $0 \%$ FHA paste. The slower setting time characteristic will be useful in mass and hot weather concreting.

Table 3: Results of Consistency and Setting Times of the FHA-Cement paste

\begin{tabular}{cccc}
\hline $\begin{array}{c}\text { Ash } \\
\begin{array}{c}\text { Content } \\
(\%)\end{array}\end{array}$ & $\begin{array}{c}\text { Initial Setting } \\
\text { Time (IST) } \\
\text { (mins) }\end{array}$ & $\begin{array}{c}\text { Final Setting } \\
\text { Time (FST) } \\
\text { (mins) }\end{array}$ & $\begin{array}{c}\text { W/C } \\
\text { Ratio }\end{array}$ \\
\hline 0 & 145 & 195 & 0.30 \\
5 & 190 & 205 & 0.28 \\
10 & 210 & 240 & 0.26 \\
15 & 235 & 285 & 0.24 \\
20 & 220 & 267 & 0.22 \\
25 & 208 & 245 & 0.20 \\
\hline
\end{tabular}

\subsection{Compressive Strength of the FHAC}

The result of the compressive strength test is shown in Figure 1. The compressive strength of 28day plain concrete was $24.98 \mathrm{~N} / \mathrm{mm}^{2}$. The value increased by $7.65 \%$ to $26.89 \mathrm{~N} / \mathrm{mm}^{2}$ at $5 \%$ FHA. The same trend was reported with the concrete produced with Guinea Corn Husk Ash (GCHA) as partial replacement for cement [15]. This trend will therefore require further investigations. However, the values decreased with further increase in ash content. It is apparent that a $5 \%$ replacement level will produce the optimum strength. However the trend of the compressive strength shows that replacing cement with more than $10 \%$ FHA will not give required strength for strong concrete that is capable of bearing heavy load, as it decreased by $23.5 \%$ to $19.11 \mathrm{~N} / \mathrm{mm}^{2}$. Reports on Corn Cob Ash (CCA) Cement Concrete [21] on the effect of admixtures, showed that compressive strength improved by $9.99 \%$ with accelerator, by $29.1 \%$ with plasticizer and by $14.2 \%$ with water reducer and retarder. This suggests that concrete from pozzolanas may produce higher strengths if injected with admixtures. However this will need to be investigated for other ashes. A comparative study report [22] on some agro waste ashes showed that compressive 
strength of concretes made from them generally decreased in values from 10 or $20 \%$ replacement levels. These were with ashes from Barbara Nutshell (35\% reduction at $10 \%$ replacement), Bone Powder (7.14\% reduction at $10 \%)$, Groundnut $(16 \%$ at $10 \%)$ and Wood (45\% at $10 \%)$. This is most likely due to lack of adequate free lime released from the oxidation of $\mathrm{C}_{3} \mathrm{~S}$ and $\mathrm{C}_{2} \mathrm{~S}$.

A previous report [23] on the use of Bagasse Ash replacement showed increase in strength of the concrete so produced at $10-30 \%$ replacement levels.

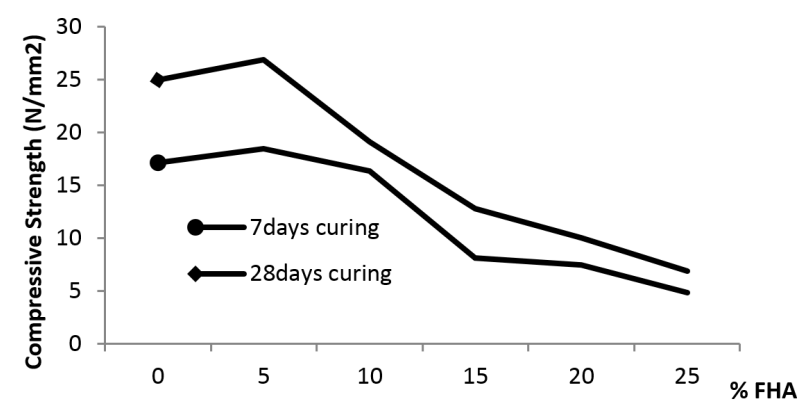

Fig.1: Compressive Strength of FHAC

\subsection{Flexural Strength of FHAC}

Shown in Figure 2 is the result of the Flexural Strength test. The Modulus of Rupture which is a measure of the Flexural Strength decreased as percentage of FHA increased. A similar Report [24] on tensile strength of high volume Palm Oil Fuel Ash (POFA) concrete was found to be lower than those of normal concrete as well.

The trend suggests that the FHA pozzolana increased the brittleness of concrete.

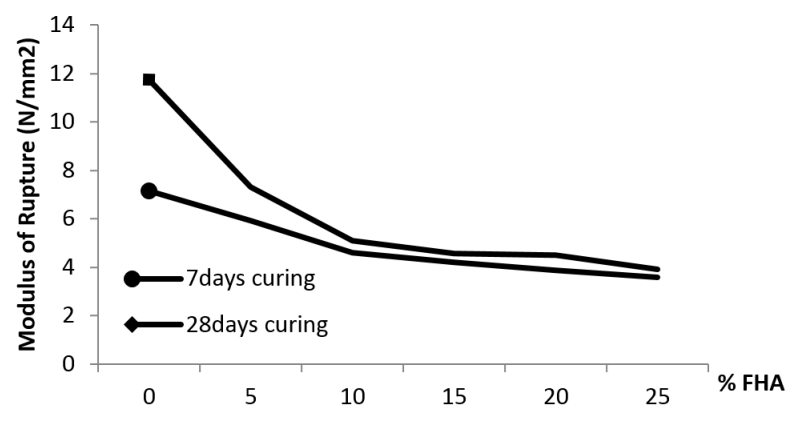

Fig. 2: Flexural Strength of FHAC

\subsection{Density of FHAC}

The result of the density test is shown in Figure 3. The density value slightly increased from $0 \%$ FHA level to an optimum value at $5 \%$ before decreasing, for the 28day FHAC. The trend is similar to that of compressive strength. However, the FHAC cannot be classified as a lightweight concrete.

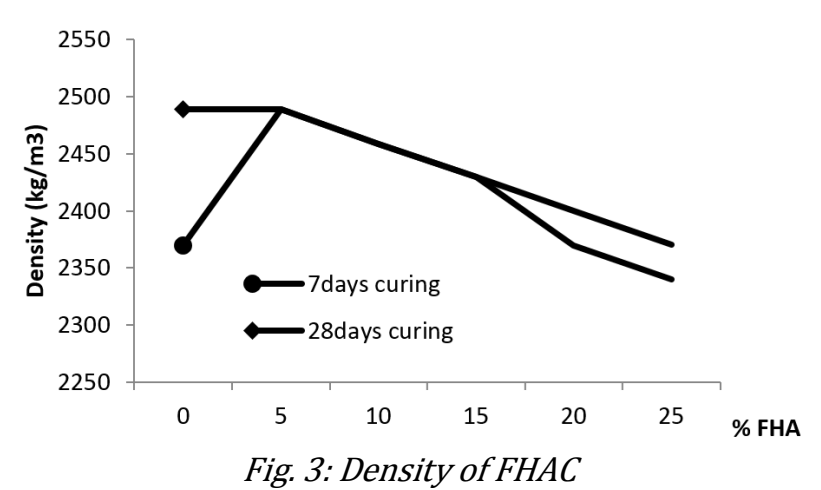

\section{CONCLUSION}

Fonio Husk Ash has been studied and found to be a pozzolana. It can be used to replace cement in concrete production up to $10 \%$ without affecting the compressive strength. The optimum percent level is however $5 \%$. The almost insignificant $\mathrm{C}_{3} \mathrm{~S}$ component content may have affected the quantity of free lime available to react with the silicate in FHA to sustain a stronger concrete mass beyond the optimum $5 \%$ level. But this was compensated for by the high $\mathrm{C}_{2} \mathrm{~S}$ value. Could there be a link between low $\mathrm{C}_{3} \mathrm{~S}$, high $\mathrm{C}_{2} \mathrm{~S}$ and optimum strength values at lower percent levels?. The concrete also possesses setting times that were above plain concretes, that makes it more suitable for use in hot climates and in mass concreting. This can be attributed to high $\mathrm{C}_{2} \mathrm{~S}$ value which slowed down reactivity. Admixtures may be added to improve performance and strength based earlier works reported. Further work on parameters like water absorption capacity, permeability and other durability parameters on concrete is suggested.

\section{REFERENCES}

[1] Adaba, C.S. Agunwamba, J.C. Nwoji, C.U. Onya, O.E. Ozeh, S. "Comparative Cost and Strength Analysis of Cement and Aggregate Replacement Materials". Nigerian Journal of Technology, Vol. 31, No. 2, 2012, pp.111 -115.

[2] American Society for Testing Materials, ASTM C618: Specification For Fly Ash and Raw or Calcined Natural Pozzolana for use as Mineral/Admixture in Portland Cement Concrete. 1981.

[3] Lea, F. M. The Chemistry of Cement and Concrete, Edward Arnolds, London, 1970. pp. 358-398.

[4] Neville, A. M. Properties of Concrete, Pearson Education, Delhi, 2003. pp. 9-15.

[5] Nagataki, S. "Mineral Admixtures in Concrete: State of the Art and Trends", Special Publication, Materials Journal, Vol. 144, 1994. pp. 447-482.

Vol. 35, No. 1, January, 2016 
[6] Atkinson, C. J., \& Sakai, E., Eco-labelling of Building Materials and Building Products. Building Research Establishment Information Paper.Vol.11, Number 93, 1993.

[7] Abalaka, A. E and Okoli, O. G. "Strength Development and Durability Properties of Concrete Containing Pre-Soaked Rice Husk Ash". Construction Science, Vol.14, Number 4, 2013.

[8] Rashid, M. H.Ali, M. Kand Ahmed, T. U. "Mortar Incorporating Rice Husk Ash: Strength and Porosity", European Journal of Scientific Research. Vol. 40, Number 3, pp. 471, 2010.

[9] Chik, F. A., Jaya, R. P., Bakar, B. H. and Johari, M. A. "Effect of Rice Husk Ash to the Performance of Concrete Block", International Journal of Applied Science \& Technology, Vol.1, Number 3, p.53, 2011

[10] Sinulingga, K., Agusnar, H., Amin, Z., Wirjosentono, B. "The effect of three different types of rice husk ash as Admixture for Ordinary Portland Cement". Applied Mechanics \& Materials, Vol. 679, 2014, p. 228

[11] Hashem, F., Amin, M., El-Gamal, S.“Improvement of acid resistance of Portland cement pastes using rice husk ash and cement kiln dust as additives", Journal of Thermal Analysis \& Calorimetry, Vol. 111 Number 2, 2013, p. 1391.

[12] Olutoge, F. A. Quadri, H. A., Olafusi, O. S. "Investigation of the Strength Properties of Palm Kernel Shell Ash Concrete", Engineering, Technology \& Applied Science Research, Vol.2, Number 6, 2012, p. 315

[13] Sumrerng R.“Use of Palm Oil Fuel Ash to Improve Chloride and Corrossion Resistance of High Strength and High Workability Concrete". Journal of University of Engineering Ukraine”.Vol.1, Number 1, 2009.

[14] Holmer S. Jnr and Moises F. "Pozzolanic Behavior of Bamboo Leaf Ash". Journal of Indian Research Institute, Vol. 3, Number 2, 2010
[15] Ndububa, E. E. and Nurudeen, Y., "Effect of Guinea Corn Husk Ash as Partial Replacement for Cement in Concrete, IOSR Journal of Mechanical and Civil Engineering (IOSR-JMCE), Vol. 12, Issue 2, Ver. I (Mar - Apr. 2015), pp. 40-45

[16] British Standards Institution, BS 1881: Part 104: Method for Determination of Vebe Time. London. BSI.1983.

[17] British Standards Institution, BS 812-109: 1990 Testing aggregates -Part 109: Methods for Determination of Moisture Content

[18] America Society for Testing and Materials ASTM C 109.Standard Test Method for Compressive Strength of Hydraulic Cement Mortars.1981.

[19] America Society for Testing and Materials ASTM C 78 - 94. Test for Flexural Strength of Concrete (Using Simple Beam with Third Point Loading), 1981

[20] British Standards Institution, BS 1881-114: 1983 Testing Concrete -Part 114: Methods for Determination of Density of Hardened Concrete

[21] Raheem, A. A. Oyebisi, S. O. Akintayo, S. O. and Oyeniran, M. I. "Effects of Admixtures on the Properties of Corn Cob Ash Cement Concrete". Leonardo Electronic Journal of Practices and Technologies, Vol. 16, 2010, pp.13-20

[22] Manasseh, J. "A Review of Partial Replacement of Cement with some Agro Wastes". Nigerian Journal of Technology, Vol. 29, No 2, 2010, pp.12-20

[23] Nuntachai, C. Chai, J. Kraiwood, K. "Utilization of Bagasse Ash as a Pozzolanic Material in Concrete". Construction and Building Materials, Vol. 23, Issue 11, 2009, pp. 3352-3358

[24] A. A. Awal, S. K. Nguong, "A Short-Term Investigation on High Volume Palm Oil Fuel Ash (POFA) Concrete". 35 th Conference on OUR WORLD IN CONCRETE \& STRUCTURES: 25 - 27,Singapore, August 2010. 